\title{
ADVANCE IN ULTRASONIC SPRAY PYROLYSIS (USP) FOR THE SYNTHESIS OF GOLD NANOPARTICLES
}

\author{
Srećko R. Stopića ${ }^{\text {, Bernd G. Friedrich }}{ }^{\mathrm{b}}$ \\ RWTH Aachen University, IME Process Metallurgy and Metal \\ Recycling, Aachen, Federal Republic of Germany \\ a e-mail: sstopic@ime-aachen.de, corresponding author, \\ ORCID iD: (i)https://orcid.org/0000-0002-1752-5378 \\ b e-mail: bfriedrich@ime-aachen.de, \\ ORCID iD: (1)https://orcid.org/0000-0002-2934-2034
}

DOI: 10.5937/vojtehg68-27948; https://doi.org/10.5937/vojtehg68-27948

FIELD: Chemical technology

ARTICLE TYPE: Original scientific paper

Summary:

Introduction/purpose: Ultrasonic spray pyrolysis (USP) is usually used for the preparation of submicronic and nanosized gold powders. This is a simple method for a synthesis from an aerosol containing dissolved metallic salts such as gold chloride, gold nitrate, and gold-acetate, obtained in the ultrasonic field using frequencies ranging from 0.8 to 2.5 $\mathrm{MHz}$.

Methods: The USP method combines aerosol formation in an ultrasonic field, transport of an aerosol with a carrier gas to the reactor and final reduction of $\mathrm{HAuCl}_{4}$ with a used gas such as hydrogen and carbon monoxide. The thermal decomposition of gold acetate takes place in a neutral atmosphere such as nitrogen and argon at elevated temperatures. The chemical reduction of $\mathrm{HAuCl}_{4}$ takes place in the aqueous phase using sodium citrate and sodium boride after heating water solution.

Results: Powders of gold were obtained at room temperature using hydrogen reduction in an ultrasonic field at room temperature from $\mathrm{HAuCl}_{4}$ using a frequency of $0.8 \mathrm{MHz}$. The obtained gold particles were analysed using scanning electron microscopy (SEM) and energy disperse spectroscopy (EDS). The formed particles are round and agglomerated. An increase in temperature to $260^{\circ} \mathrm{C}$ and $500^{\circ} \mathrm{C}$ leads to the formation of spherical and cylindrical gold particles.

ACKNOWLEDGEMENT: The author would like to thank Mr. Sava Maksimovic and Prizma Company, Kragujevac, Serbia, for their continuous support in the synthesis of nanosized gold particles and for their permission to use some photos from their deveopment programme focusing on a new ultrasonic generator and a USP horizontal experimental setup. 
Conclusion: New improved equipment for an ultrasonic spray pyrolysis synthesis of gold powder from $\mathrm{HAuCl}_{4}$ with hydrogen reduction was offered by PRIZMA, Kragujevac, Serbia, enabling a controlled reduction process with better prevention of piezo transducers in an ultrasonic field and increased aerosol production and its transport to the reaction furnace.

Key words: gold, advancement, ultrasonic spray pyroylsis, synthesis.

\section{Introduction}

Various strategies are used for the synthesis of gold nanoparticles. Traditionally, physicochemical techniques have increased environmental concerns due to the reduction of metal ions followed by surface modification, toxic compounds added for stability, and dangerous byproducts. The currently used nanoparticle synthesis based on chemical and physical methods at high temperature and pressure values, with reduced introduction of stabilizing agents, asks for a new nanoparticle synthesis based on improved ultrasonic spray pyrolysis of water solutions at a room temperature and atmospheric pressure, in the presence of some additives and stabilizing agents. A green synthesis method provides a faster metallic nanoparticle production by offering an environmentally friendly, simple, economical, and reproducible approach.

Gold as a noble metal has resistance to corrosion and it is mostly used in jewellery and currency. Schmid and Corain (2003, pp.3081-3098) studied the synthesis, structures, electronics, and reactivity of gold nanoparticles. Both physical and chemical methods are usually used in order to produce gold nanoparticles. A decrease in the size of gold nanoparticles had dramatic consequences on their physical and chemical properties.

Gold nanoparticles can accelerate the oxidation processes better than micron-sized ones (Bond, 2008, pp.235-241). Examining the published results and especially the patents granted before 1978 reveals frequent observations of the potential of gold as a catalyst. (Qi, 2008, pp.224-234) reported the production of propylene oxide over nanosized gold catalysts in the presence of hydrogen and oxygen. Polte et al (2010, 1296-1301) reported the mechanism of gold nanoparticle formation in the classical citrate synthesis method derived from coupled in situ XANES and SAXS Evaluation. The same method was used by Turkevich in 1953 (Turkevich et al, pp.670-673). This method confirmed good quality control of the particle size, in the range between 22 and $120 \mathrm{~nm}$. A big disadvantage of the citrate method is that high excess remains in the final solution. The residual citrate and sodium in the solution, acting as a 
passivation layer on the surface of nanosized gold, reduce the effectiveness of surface functionalization with other biological markers.

The efficient recovery of scraps and wastes in gold jewellery manufacture is a vital component of a profitable manufacturing business, irrespective of whether it is a large factory or a small, traditional workshop (Corti, 2002, pp.111-130). Possible techniques for gold purification contain: 1) cupellation, 2) Miller chlorination process, Wohlwill electrolytic process, 3) Fizzer cell, 4) solvent extraction, 5) Aqua regia process, and 6) pyrometallurgical process. The process for recovering gold from a chloride solution involves adding finely divided activated carbon to the solution for the reduction of gold metal and subsequent absorption of gold metal by carbon (Piret et al, 1977). The most used methods for the synthesis of gold powder are presented in Table 1.

Table 1 - Most used methods for the synthesis of gold powder

Таблица 1 - Наиболее распространенные методы получения золотого порошка Табела 1 - Најчешће коришћене методе за синтезу праха од злата

\begin{tabular}{|c|c|c|c|c|}
\hline Author & Method & Precursor & $\begin{array}{l}\text { Reducing } \\
\text { agent }\end{array}$ & Particle Size $(\mathrm{nm})$ \\
\hline $\begin{array}{l}\text { (Schmid \& Corain, } \\
\text { 2003, pp.3081- } \\
\text { 3098) }\end{array}$ & Reduction & $\mathrm{HAuCl}_{4}$ & 5 & Spherical \\
\hline $\begin{array}{l}\text { (Polte et al, 2010, } \\
\text { pp.1296-1301) }\end{array}$ & Reduction & $\mathrm{HAuCl}_{4}$ & $\mathrm{Na}_{3} \mathrm{C}_{6} \mathrm{H}_{5} \mathrm{O}_{7}$ & $\begin{array}{l}\text { - Spherical } \\
\text { - below } 100 \mathrm{~nm}\end{array}$ \\
\hline (Piret et al, 1977) & $\begin{array}{l}\text { Reduction, } \\
\text { precipitation }\end{array}$ & $\begin{array}{l}\text { Precious metal } \\
\text { containing } \\
\text { chloride } \\
\text { leach }\end{array}$ & $\mathrm{Zn}, \mathrm{Fe}$ & $\begin{array}{l}\text { - Agglomerated } \\
\text { irregular form } \\
\text { - above } 1000 \mathrm{~nm}\end{array}$ \\
\hline $\begin{array}{l}\text { (Young et al, } \\
\text { 2011) }\end{array}$ & Reduction & $\mathrm{HAuCl}_{4}$ & $\mathrm{CO}$ & $\begin{array}{l}\text { Spherical } \\
2-100 \mathrm{~nm}\end{array}$ \\
\hline $\begin{array}{l}\text { (Tréguer- } \\
\text { Delapierre, 2008, } \\
\text { pp.195-207) }\end{array}$ & Reduction & $\mathrm{HAuCl}_{4}$ & $\mathrm{NaBH}_{4}$ & $\begin{array}{l}\text {-Non-spherical } \\
\text {-below } 100 \mathrm{~nm}\end{array}$ \\
\hline $\begin{array}{l}\text { (Rudolf et al, } \\
\text { 2012, pp.595-612) }\end{array}$ & $\begin{array}{l}\text { Ultrasonic } \\
\text { spray } \\
\text { pyrolysis } \\
\text { \&reduction }\end{array}$ & $\begin{array}{l}\text { Water solution } \\
\text { after dissolution } \\
\text { of jewellery } \\
\text { scrap in } \\
\mathrm{HNO}_{3} / \mathrm{HCl}\end{array}$ & $\mathrm{H}_{2}$ & $\begin{array}{l}\text { - Spherical, } \\
\text { cylindrical, } \\
\text { triangular } \\
\text { - below } 100 \mathrm{~nm}\end{array}$ \\
\hline $\begin{array}{l}\text { (Turkevich et al, } \\
1953, \text { pp.670-673) }\end{array}$ & $\begin{array}{l}\text { Reduction in } \\
\text { an aqueous } \\
\text { phase }\end{array}$ & $\mathrm{HAuCl}_{4}$ & $\mathrm{Na}_{3} \mathrm{C}_{6} \mathrm{H}_{5} \mathrm{O}_{7}$ & $\begin{array}{l}\text { Spherical } \\
20-150 \mathrm{~nm}\end{array}$ \\
\hline
\end{tabular}

Young et al (2011) reported on a successful hydrometallurgical production of nanosized gold from $\mathrm{HAuCl}_{4}$ using carbon monoxide gas as 
a selective gold precipitating agent. The size of gold nanoparticles is adjustable from 4 and $100 \mathrm{~nm}$ by altering the concentration of $\mathrm{HauCl}_{4}$ and the inlet carbon monoxide injection flow rate. Fast synthesis rates at room temperature ease tunability and the absence of cytotoxic byproducts allows these CO-based gold nanoparticles to be optimized and readily produced for biomedical and industrial application.

The development of a colloid chemistry route continues to be essential for the synthesis and manipulation of anisotropic gold nanoparticles, with the major requirements already demonstrated by Tréguer-Delapierre et al (2008, pp.195-207), such as the control of the nuclei shape and the growth on specific facets. A key feature of nonspherical nanoparticles is that their optical properties vary dramatically with their physical dimensions. In contrast to gold spherical nanoparticles, their resonance frequency is tuneable over a wide range from blue to near infrared and enables one to set the surface plasmon resonance to a wavelength or spectral region specific to a particular application. Together with a high degree of biocompatibility of gold, these structures show potential in a wide variety of biological applications (Rudolf et al, 2012, pp.595-612). Spherical, round and cylindrical nanosized particles of gold were synthesized by ultrasonic atomization of chloride-nitrate solutions based on gold from jewellery scraps and an alloying element ( $\mathrm{Cu}, \mathrm{Ag}, \mathrm{Zn}, \mathrm{In}$, and $\mathrm{Ni})$. A subsequnt decomposition of the obtained solution at temperatures of $300^{\circ} \mathrm{C}$ and $800^{\circ} \mathrm{C}$ in hydrogen and nitrogen atmospheres was performed. The aerosols produced by the resulting frequencies of 0.8 and $2.5 \mathrm{MHz}$ were transported by a carrier, mostly a reduction gas, into a hot reactor, where aerosol droplets undergo drying, droplet shrinkage, solute precipitation, thermolysis, and sintering to form particles with different forms.

The gold formation from $\mathrm{HAuCl}_{4}$ takes place in two steps (Stopic et al, 2013, pp.577-583) using ultrasonic spray pyrolysis:

$$
\text { First step: } 2 \mathrm{HAuCl}_{4}=\mathrm{Au}_{2} \mathrm{Cl}_{6}+2 \mathrm{HCl}
$$

$$
\text { Second step: } \quad \mathrm{Au}_{2} \mathrm{Cl}_{6}+3 \mathrm{H}_{2}=2 \mathrm{Au}+6 \mathrm{HCl}
$$

Under the spray pyrolysis conditions, hydrogen was passed continuously through the quartz tube $(I=1.0 \mathrm{~m}, b=20 \mathrm{~mm})$ at a flow rate of $1 \mathrm{l} / \mathrm{min}$. Then, atomized droplets of the solution from gold auric acid were transported further by hydrogen to the furnace for the subsequent reduction of gold chloride at a different reaction temperature between 
$260^{\circ} \mathrm{C}$ and $500^{\circ} \mathrm{C}$. After the completed reduction process, the obtained gold nanopowder was collected in a reaction tube and in two bottles with ethanol and water. The presence of triangular, rounded, and irregular particles revealed that the synthesis of gold nanoparticles is possible at temperatures lower than the melting point of gold.

On the other hand, both the methods and the parameters for the synthesis depend on the available equipment capable of supplying suitable conditions for ultrasonic spray pyrolysis and a subsequent treatment of the prepared powder. Kozhukharov and Tchaoushev (2013, pp.111-118) showed a basic construction of the equipment for spray pyrolysis in a vertical chamber, a horizontal chamber and a chamber for film deposition. The horizontal construction permits the separation of drops and particles based on their size. The basic operation units of each spray pyrolysis installation, regardless of its construction, are a spray nozzle or a nebulizer, a heat source and a product collector or a substrate for deposition. The employment of an ultrasonic nebulizer instead of a conventional nozzle enables production of nanomaterials in a form of monodispersive fine powders with easy particle size control by the variation of the ultrasound frequency and the concentration of water solution.

The present work is our attempt to summarize the basic parts and types of equipment as well as the conditions for the preparation of gold nanoparticles using ultrasonic spray pyrolysis. Regarding the very acidic and corrosive properties of a precursor solution such as $\mathrm{HAuCl}_{4}$, the aim is to propose new equipment for an environmental friendly process for the synthesis of gold nanoparticles aiming for a continuous process in laboratory conditions with on-line control of an injection of precursor, level of liquid in an ultrasonic atomizer and improved transport with increased residence time in the reactor.

\section{Laboratory scale horizontal USP equipment without a furnace}

The experimental setup for the synthesis of nanogold particles is shown in Figure 1. The proposed equipment contains a gas station for hydrogen (a bottle with hydrogen and a flowmeter with a connection), a thermostat and an ultrasonic spray pyrolysis generator, as shown in Figure 1. 


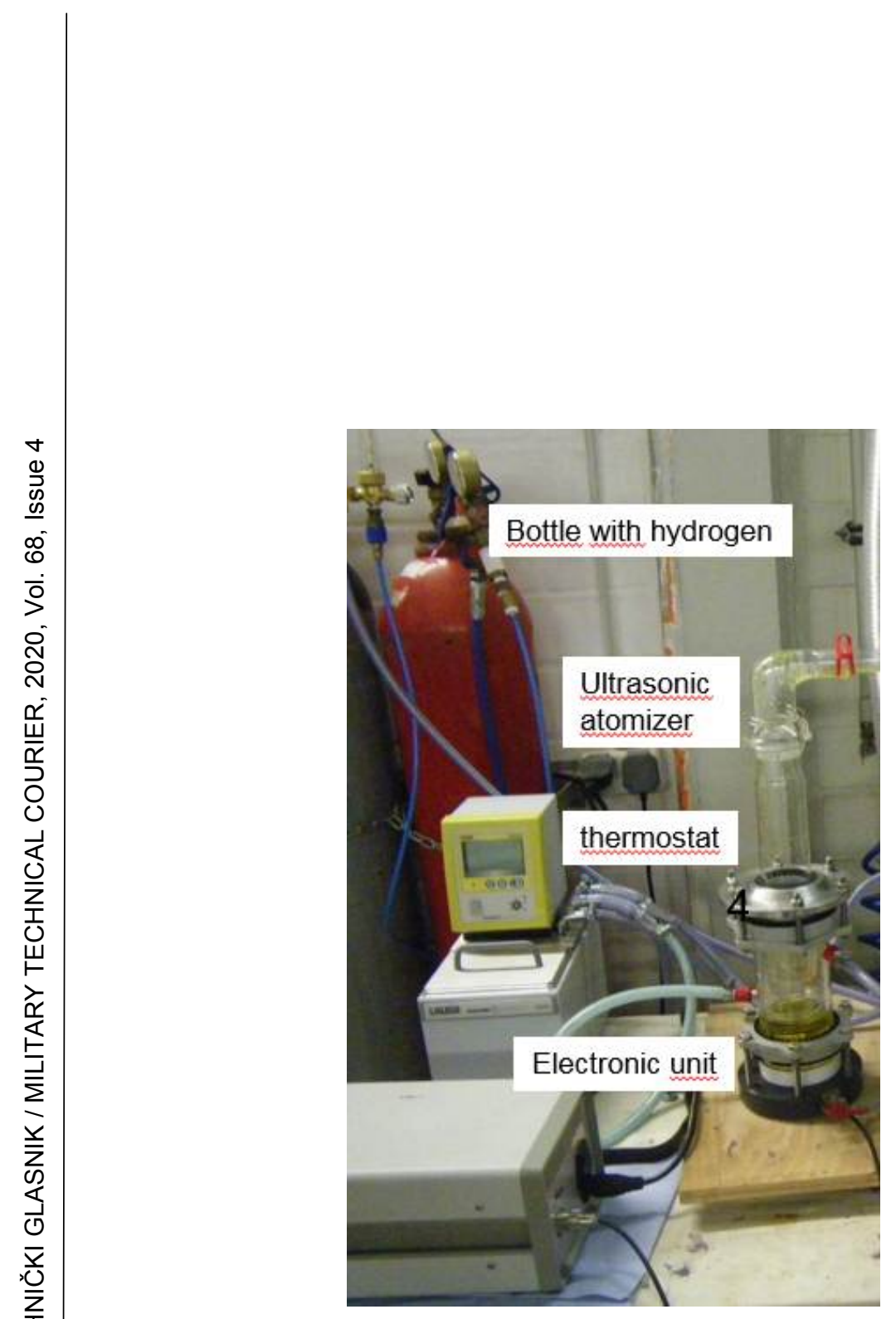

Figure 1 - One step USP lab-scale horizontal equipment

Pис. 1 - Горизонтальное устройство для получения порошка путем одношагового ультразвукового распыления раствора

Слика 1 - Хоризонтална апаратура за синтезу прахова ултразвучним распршивањем раствора у једном кораку

The thermostat is responsible for the prevention of overheating of the piezo transducer. Our first results are related to a new study of the preparation of gold nanoparticles from gold auric acid $(1 \mathrm{~g} / \mathrm{L})$ by ultrasound-assisted reduction using $0.8 \mathrm{MHz}$ at room temperature in hydrogen (a flow rate of $2 \mathrm{l} / \mathrm{min}$ ) in the absence of a reaction furnace. These first results have confirmed the formation of gold nanoparticles under the above mentioned conditions, as shown in Figure 2, where a scanning electron microscope (ZEISS DSM 982 Gemini, Carl Zeiss Microscopy $\mathrm{GmbH}$, Oberkochen, Germany) was used for the characterization of the obtained gold powders. The SEM images were used to observe the surface morphology of the particles formed at 
different parameter sets. The qualitative characterization of the impurity level was performed by the energy disperse spectroscopy (EDS) analysis with an $\mathrm{Si}(\mathrm{Bi}) \mathrm{X}$-ray detector connected to the SEM and a multi-channel analyser.

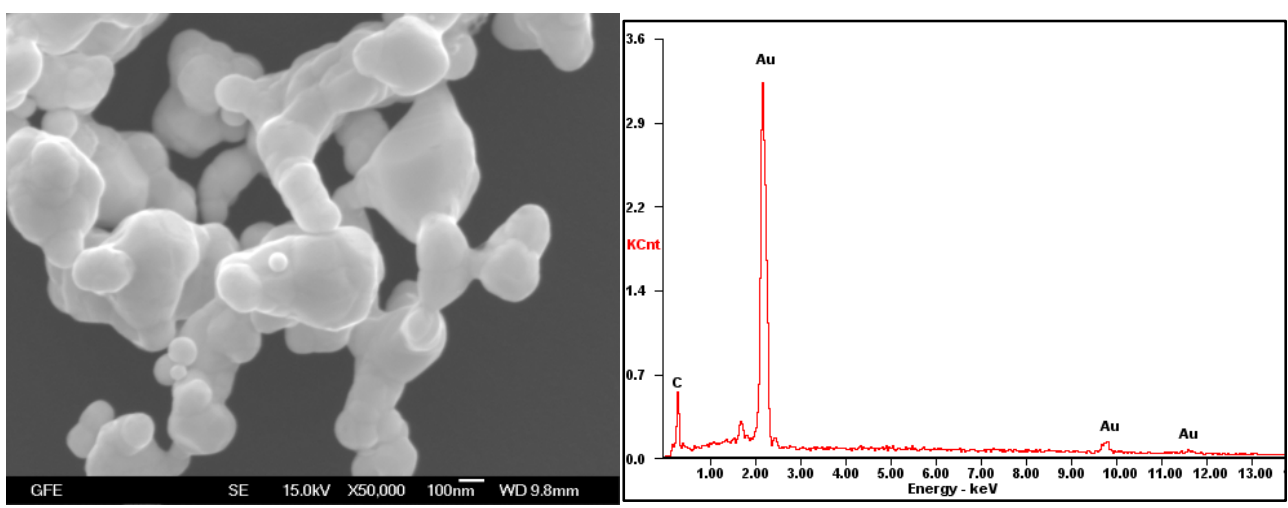

Figure 2 - SEM and EDS analysis of the gold particles obtained in the ultrasound field at room temperature

Puc. 2 - СЭМ и ЭРС анализ золотых порошков, полученных в ультразвуковом поле при комнатной температуре

Слика 2 - Скенирајућа електронска микроскопија и енергетска дисперзивна спектроскопија прахова злата добијених у ултразвучном пољу на собној температури

These results confirm that ultrasound can induce the reduction of $\mathrm{HAuCl}_{4}$ with hydrogen. This study has to establish the current limitations of this induced synthesis. The relationship between the ultrasound frequency and the produced nanoparticles will be investigated in order to explain this phenomenon. Kinetic studies of the reduction of $\mathrm{Au}$ (III) complex ions and the gold nanoparticle formation with hydrogen at room temperature will be studied. The rate law and the rate limiting step will be established. The Finke-Watzky Two-Step Nucleation-Autocatalysis Model will be studied for gold nanoparticles. The two-step particle synthesis mechanism, also known as the Finke-Watzky (Watzky \& Finke, 1997, pp.10382-10400) mechanism, has emerged as a significant development in the field of nanoparticle synthesis. It explains a characteristic feature of the synthesis of transition of metal nanoparticles, an induction period in the precursor concentration followed by its rapid sigmoidal decrease. The two-step mechanism considers slow continuous nucleation and autocatalytic growth of particles directly from the precursor as its two kinetic steps. 


\section{furnace}

In order to improve the gold preparation by USP and hydrogen reduction, an additional furnace was used in the experimental set, as shown in Figure 3. With a concentration of gold in auric acid of $1.25 \mathrm{~g} / \mathrm{L}$, temperature of $260^{\circ} \mathrm{C}$ and $500^{\circ} \mathrm{C}$, a hydrogen flow rate of $(2 \mathrm{~L} / \mathrm{min})$, and an ultrasound frequency of 0.8 and $2.5 \mathrm{MHz}$, the obtained particles have cylindrical and spherical forms, as shown in Figure 4. (Dittrich et al, 2011, pp.1065-1076)

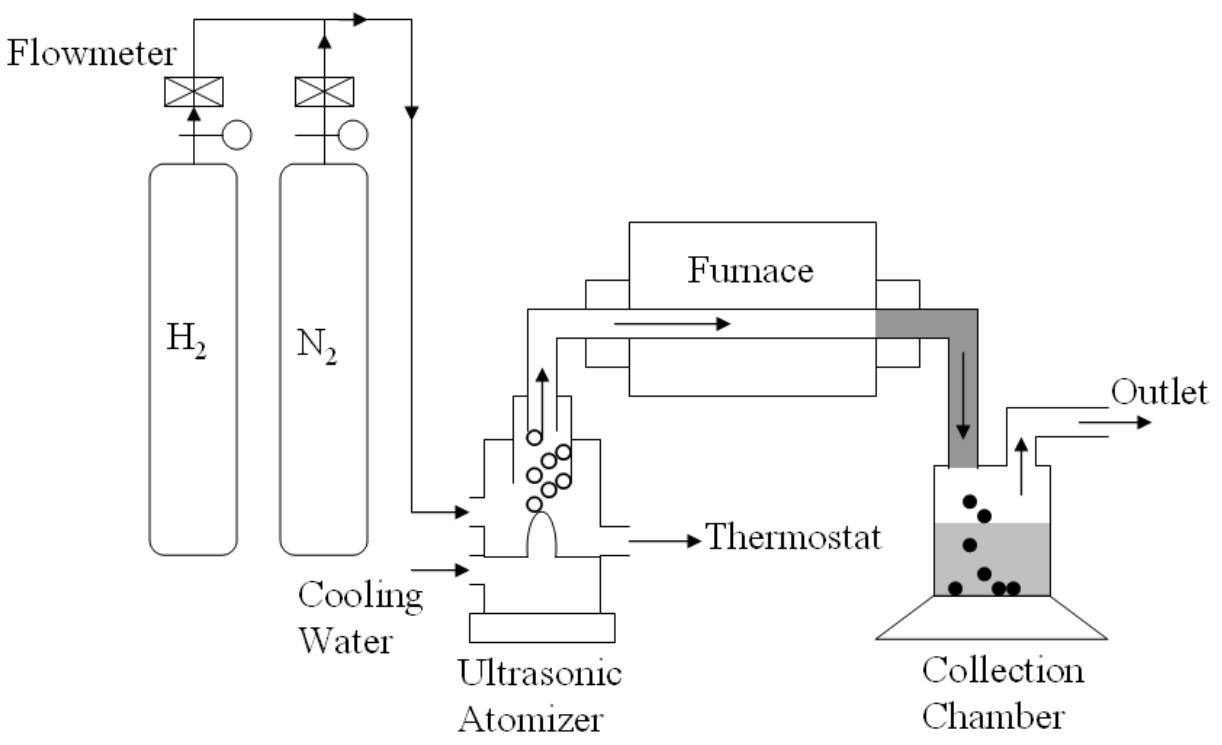

Figure 3 - Schematic drawing of the experimental apparatus for the synthesis of gold nanoparticles from a gold-chloride solution

Puc. 3 - Схема экспериментального устройства для извлечения наночастиц золота из раствора хлорида золота

Слика 3 - Шематски приказ експерименталне апаратуре за синтезу наночестица злата из раствора злато-хлорида

Three most important components of the USP equipment contain: 1) aerosol production in an ultrasonic field, 2) aerosol transport to the reaction furnace and the reduction of $\mathrm{HAuCl}_{4}$ to $\mathrm{Au}$, and 3) collection of gold particles in water and alcohol with its stabilization. 


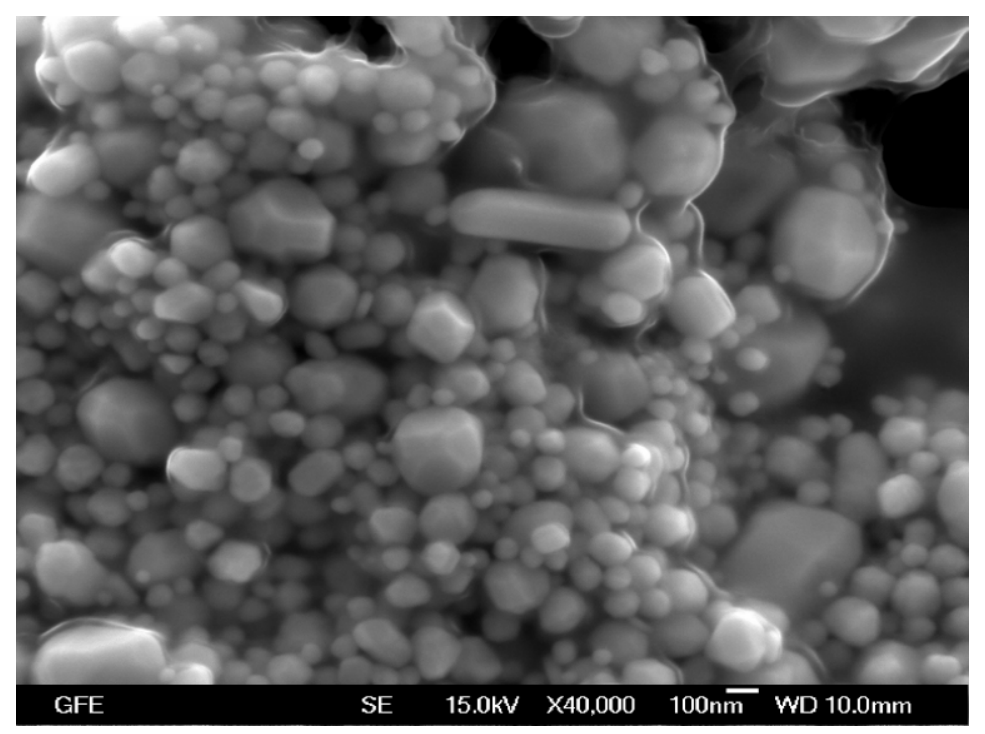

Figure 4 - Gold nanoparticles produced by USP $\left(T=260^{\circ} \mathrm{C}, 2.5 \mathrm{MHz}\right)$

Puc. 4 - Наночастицы золота, полученные ультразвуковым распылением раствора $\left(T=260^{\circ} \mathrm{C}, 2.5 \mathrm{MHz}\right)$

Слика 4 - Наночестице злата произведене ултразвучним распршивањем раствора $\left(T=260^{\circ} \mathrm{C}, 2,5 \mathrm{MHz}\right)$

The big disadvantage of this process is frequent destruction of the piezo-transducer in contact with an acidic solution in the ultrasonic generator during aerosol production. This problem becomes very urgent for the solution obtained from secondary sources based on the dissolution of jewelry scraps in a high acidic solution of aqua regia, where the solution $\mathrm{pH}-\mathrm{Value}$ is negative and the gold concentration is higher than $20 \mathrm{~g} / \mathrm{l}$. The losses of aerosol were detected during aerosol transport to the reactor. A higher flow rate of the carrier gas brings better transport of aerosol to the reactor furnace, but the residence time is shorter. Finally, collection of gold nanoparticles using either an electrofilter or a wet scrubber system is an open question for the future work in order to increase collection efficiency. A fully controlled process with an continuous injection is of the highest challenge in particular.

\section{Improvement of the horizontal USP equipment}

Regarding the previously mentioned disadvantages of the USP processes, some improvements are required and achieved firstly for the aerosol production using a new ultrasonic atomizer: PROFI SONIC and 
PRIZNano, Kragujevac, Serbia. The main aim is to enable environmentally friendly aerosol production in an ultrasonic generator.

\section{PROFI SONIC ultrasonic generator}

Aerosol production from water solution was performed using the ultrasonic nebuliser (power: 55 W), PROFI SONIC, PRIZMA Kragujevac, transmitting the energy of ultrasonic vibrations (ultrasonic frequency of 1.7 $\mathrm{MHz}$ ) from the vibrator located at the bottom of the water tank into water, as shown in Figure 5. Ultrasonic vibrations are transmitted to the medication cup (volume of $300 \mathrm{ml}$ ) through water in the water tank. Ultrasonic vibrations emit medication from the medication cup (like a fountain) and it is dispersed as aerosol. The air from the fan carries this nebulised medication out of the medication cup. The maximum production of aerosol amounts to $3 \mathrm{ml} / \mathrm{min}$ with a droplet size between $0.5-5 \mu \mathrm{m}$. The operation temperature is between 15 and $40^{\circ} \mathrm{C}$. This ultrasonic generator allows the water solution of metallic salt to be separated from the piezo transducer, and protected during this work. This atomizer has also a control unit and a possibility to monitor the required time for the production of an aerosol.
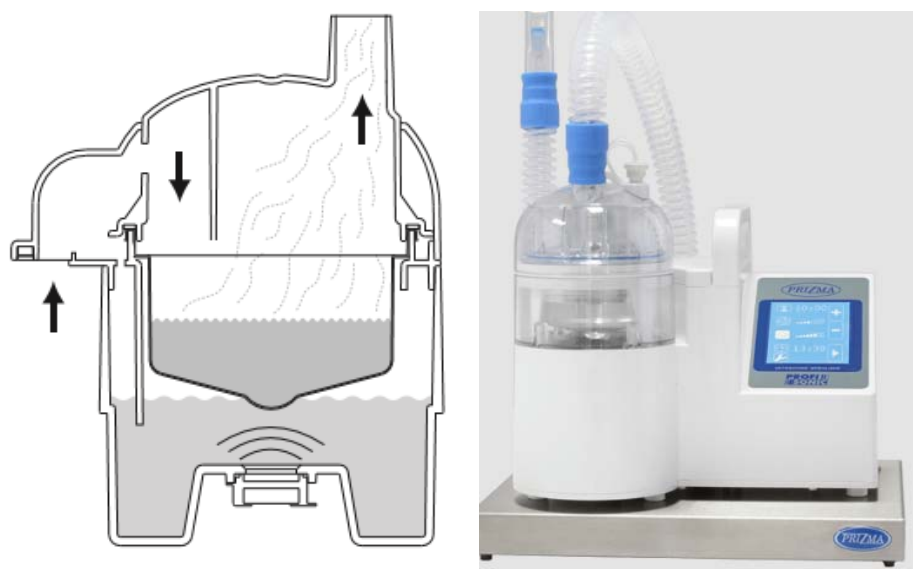

Figure 5 - Principle of aerosol production with an ultrasonic atomizer

Puc. 5 - Принцип получения аэрозоля с помощью ультразвукового распылителя Слика 5 - Принцип производње аеросола са ултразвучним атомизером

\section{PRIZNano Generator}

The usage of three piezo-electric crystals with a frequency of 1.7 $\mathrm{MHz}$ guarantees a large atomization capacity up to $1.2 \mathrm{l} / \mathrm{h}$, which provides the production of large quantities of aerosol, ideal for 
independent use (humidification of large spaces) or, in a combination with other systems, for the production of nanoparticles, as shown in Figure 6. The result of new development by PRIZMA, Kragujevac, Serbia, is a compact PRIZnano ultrasonic pyrolysis generator with the dimensions of $300 \times 300 \times 450 \mathrm{~mm}$ and a weight of $3 \mathrm{~kg}$. The atomizer can be powered from an AC power supply of $110 \mathrm{~V}$ to $240 \mathrm{~V}, 50 \mathrm{~Hz}$ or $60 \mathrm{~Hz}$, and the maximum power consumption is $150 \mathrm{~W}$. This generator was successfully used for the synthesis of metallic and oxidic particles at the RWTH Aachen University. Then, this PRIZNano is connected with a control unit as shown in Figure 6, which regulates the operation of each of three transducers. A flow meter is especially installed at an ultrasonic atomizer for the carrier gas. A special sensor is added for monitoring the solution level in the ultrasonic atomizer in order to prevent destruction of piezo transducers through the total consumption of the studied solution. The second sensor is responsible for the continuous injection of the solution in time. This type of generators does not use additional thermostats for cooling the solution in the ultrasonic atomizer. A special electronic unit controls the operations of all three piezo transducers in time, solution injection, and aerosol production power, as shown in Figure 6 (right). In contrast to the most frequently used GAPUSOL, RBI, France, this ultrasonic atomizer has shown many advantages (corrosion resistance, aerosol production and its transport, better control of transducer operation, and continuous solution injection).

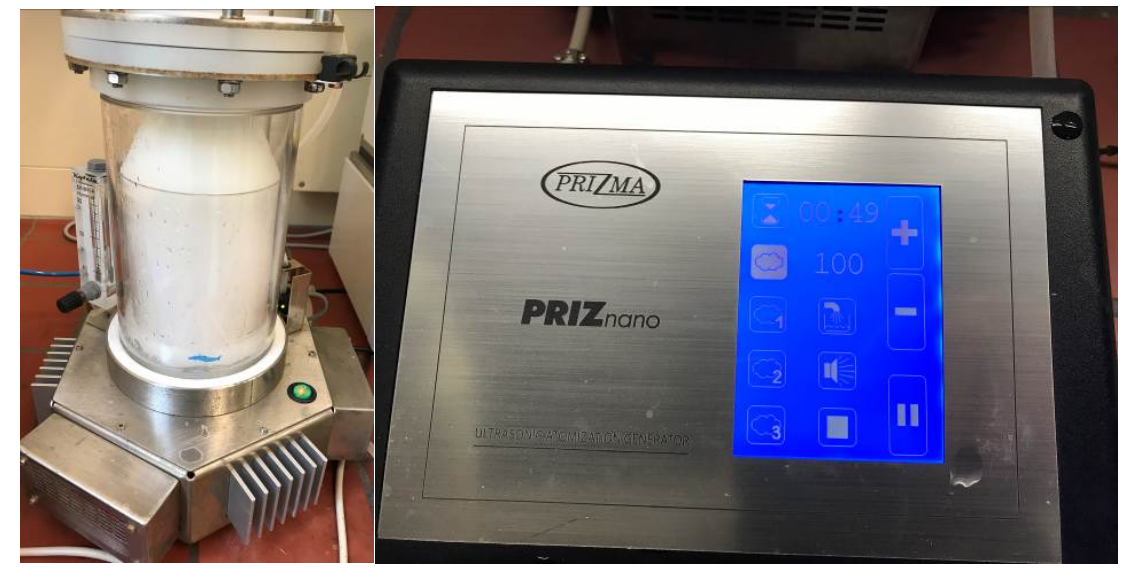

Figure 6-PRIZNano aerosol generator, Kragujevac, with the electronic control unit Puc. 6 - Генератор аэрозолей ПРИЗНано, г. Крагуевац, с электронным блоком управления

Слика 6 - Генератор ааеросола PRIZnano „Призме” из, Крагујевца, са контролном електронском јединицом 
The first measurement of the production and transport of aerosol in a PRIZNano generator from the water solution using different flow rates is shown in Figure 7.

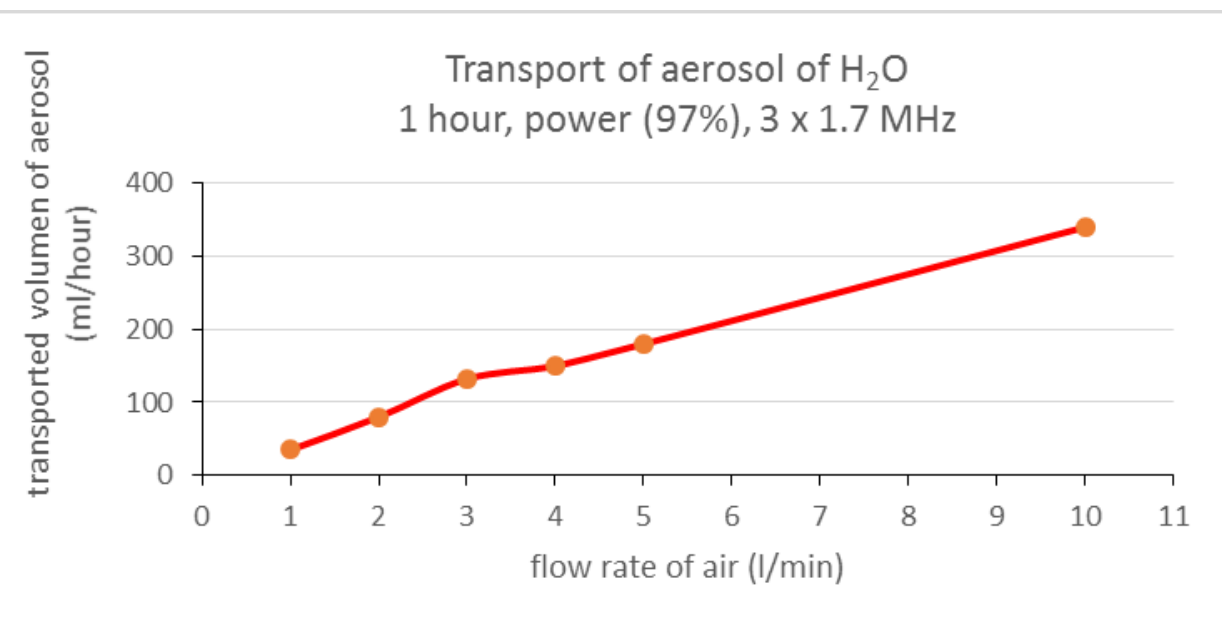

Figure 7 - Transport of aerosol depending on the air flow rate

Puc. 7 - Перемещение аэрозоля в зависимости от расхода воздуха

Слика 7 - Преношење аеросола у зависности од протока ваздуха

As shown in Figure 7, an increase in the flow rate increases the transport of aerosol.

The maximal transport is $330 \mathrm{ml}$ in $60 \mathrm{~min}$ using $10 \mathrm{l} / \mathrm{min}$.

\section{Improved horizontal USP setup}

Based on the previously mentioned improvements, new horizontal USP equipment was installed at PRIZMA, Kragujevac, Serbia. 


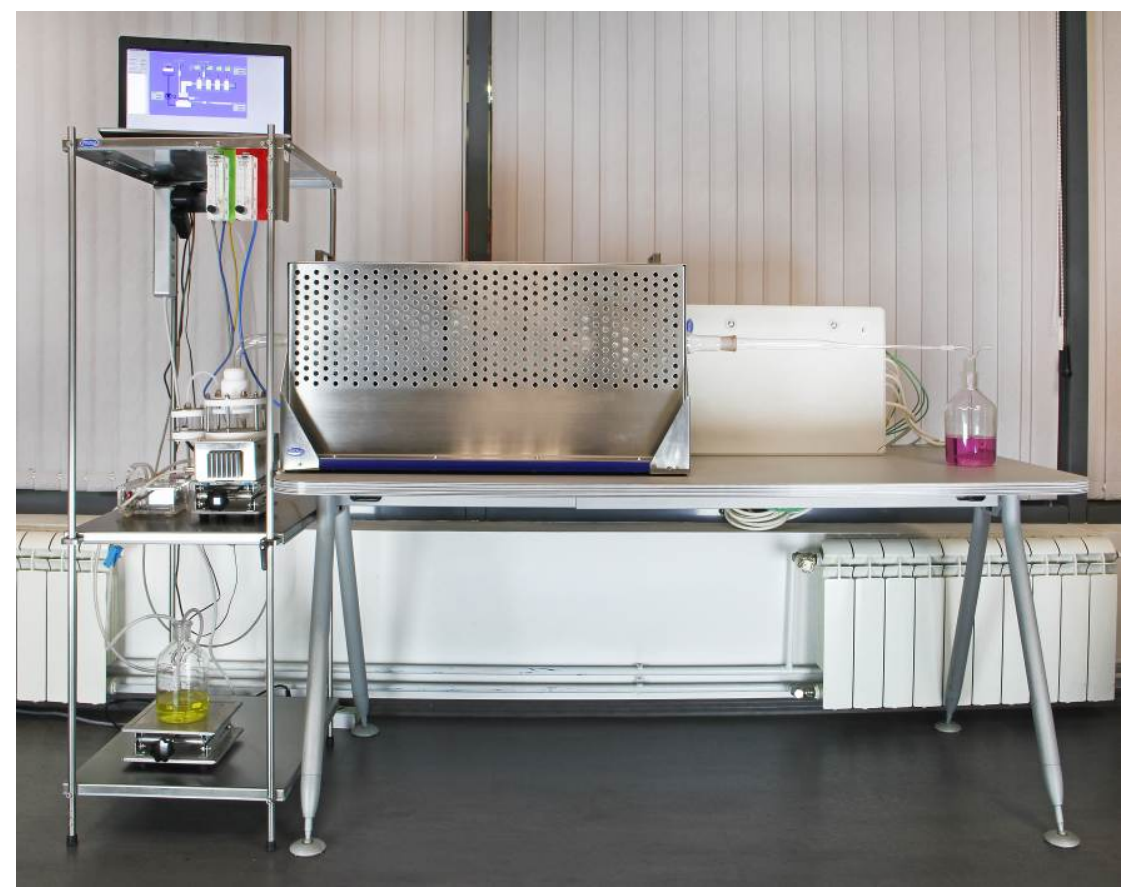

Figure 7 - Improved USP Setup: a bottle with $\mathrm{HAuCl}_{4}$ solution (yellow color), a peristaltic pump, an ultrasonic atomizer $(f=1.7 \mathrm{MHz})$, an electronic unit with on-line process control, a quartz tube, a horizontal furnace and a bottle with water for the collection of gold nanoparticles (purple color, particle size approx. 50-80 nm)

Puc. 7 - Улучшенное устройство ультразвукового распылителя: баллон с раствором $\mathrm{HAuCl}_{4}$ (желтый цвет), шланговый насос, ультразвуковой распылитель ( $f=1,7$ МГu), электронный блок управления, кварцевая трубка, горизонтальная печь и баллон с водой для извлечения наночастиц золота (фриолетовый цвет, размер частиц около 50-80 нм)

Слика 7 - Побољшана опрема за синтезу прахова ултразвучним распршивањем раствора: боца са ратвором $\mathrm{HAuCl}_{4}$, (жута боја), перистатичка пумпа, ултразвучни генератор (фрреквенца 1,7 MHz), електронска јединица са непрекидном контролом процеса, кварцна цев, хоризонтална пећ и боца са водом за сакупљање наночестица злата величине приближно између 50 и 80 nm (љубичаста боја)

\section{The advantages of new USP equipment:}

- On-line control of the liquid level in the ultrasonic atomizer,

- Continuous injection of the solution into the ultrasonic atomizer,

- Better protection of the piezo transducer, because a separate bottle with $\mathrm{HAuCl}_{4}$ solution prevents contact with the piezo transducer and its destruction, 
- Higher aerosol production and its transport to the furnace in order to decrease losses of aerosol,

- Full control of aerosol production using three transducers $(f=1.7$ Mhz) via the electronic unit,

- Improved collection of powder using a newly constructed electrofilter which is not presented in this work but is available as part of this USP equipment constructed by PRIZMA, Kragujevac, Serbia.

\section{Conclusion}

A critical analysis of the state of the art in preparation of nanosized gold particles using different reducing agents such as sodium citrate, sodium boride, zinc and iron powder, carbon monoxide, hydrogen, and phosphorus, producing spherical, cylindric and agglomerated gold particles, has made ultrasonic spray pyrolysis a highly promising method. The use of gaseous reducing agents such as hydrogen and carbon oxide leads to the synthesis of gold particles using reduction at room temperature. An increase in temperature between $260^{\circ} \mathrm{C}$ and $500^{\circ} \mathrm{C}$ supports the formation of spherical and cylindrical particles. New horizontal USP equipment offers many advantages in order to obtain one continuous controlled process, which is missing in the production of nanogold particles. Because of their very low production rate, USP processes are not industrially developed in comparison to traditional primary metallurgy for gold production. Therefore, scaling up these USP processes is a big challenge in the future related to the synthesis of nanogold.

\section{References}

Bond, G. 2008. The early History of Catalysis by Gold. Gold Bulletin, 41(3), pp.235-241. Available at: https://doi.org/10.1007/BF03214875.

Corti, C. 2002. Recovery and refining of gold jewelry scraps and waste. In: The Santa Fe Symposium - The Premier Conference For Jewelry Makers, Albuquerque, NM, pp.111-130 [online]. Available at: http://www.santafesymposium.org/2002-santa-fe-symposium-papers/2002recovery-and-refining-of-gold-jewellery-scraps-and-wastes [Accessed: 10 August 2020].

Dittrich, R., Stopic, S. \& Friedrich, B. 2011. Mechanism of nanogold formation by ultrasonic spray pyrolysis. In: Proceeding of EMC 2011 - European Metallurgical Conference, Duesseldorf, June 26-29, pp.1065-1076 [online]. Available at: http://www.metallurgie.rwthaachen.de/new/images/pages/publikationen/emc2011_id_5231.pdf [Accessed: 10 August 2020]. 
Kozhukharov, S. \& Tchaoushev, S. 2013. Spray pyrolysis equipment for various application. Journal of Chemical Technology and Metallurgy, 48, pp.111118 [online]. Available https://www.researchgate.net/publication/283826563_Spray_pyrolysis_equipme nt for_various_applications [Accessed: 10 August 2020].

Piret, N.L., Hopper, M. \& Kudelka, H. 1977. Process for recovering silver and gold from chloride solutions. US Patent number 4131454 [online]. Available at: https://patents.google.com/patent/US4131454A/en [Accessed: 10 August 2020].

Polte, J., Ahner, T.T., Delissen, F., Sokolov, S., Emmerling, F., Thünemann, A.F. \& Kraehnert, R. 2010. Mechanism of Gold Nanoparticle Formation in the Classical Citrate Synthesis Method Derived from Coupled In Situ XANES and SAXS Evaluation. Journal of the American Chemical Society, 132(4), pp.1296-1301. Available at: https://doi.org/10.1021/ja906506j.

$\mathrm{Qi}, \mathrm{C}$. 2008. The production of propylene oxide over nanometer $\mathrm{Au}$ catalysts in the presence of $\mathrm{H}_{2}$ and $\mathrm{O}_{2}$. Gold Bulletin, 41(3), pp.224-234. Available at: https://doi.org/10.1007/BF03214874.

Rudolf, R., Friedrich, B., Stopić, S., Anžel, I., Tomić, S. \& Čolić, M. 2012. Cytotoxicity of Gold Nanoparticles Prepared by Ultrasonic Spray Pyrolysis. Journal of Biomaterials Applications, 26(5), pp.595-612. Available at: https://doi.org/10.1177/0885328210377536.

Schmid, G. \& Corain, B. 2003. Nanoparticulated Gold: Syntheses, Structures, Electronics, and Reactivities. European Journal of Inorganic Chemistry, 2003(17), pp.3081-3098. Available at: https://doi.org/10.1002/ejic.200300187.

Stopic, S, Rudolf, R., Bogovic, J., Majerič, P., Čolić, M., Tomić, S., Jenko, M. \& Friedrich, B. 2013. Synthesis of Au nanoparticles prepared with ultrasonic spray pyrolysis and hydrogen reduction. Materials and Technology, 47(5), pp.577-583 [online]. Available at: http://mit.imt.si/izvodi/mit135/stopic.pdf [Accessed: 10 August 2020].

Tréguer-Delapierre, M., Majimel, J., Mornet, S., Duguet, E. \& Ravaine, S. 2008. Synthesis of non-spherical gold nanoparticles. Gold Bulletin, 41(2), pp.195-207. Available at: https://doi.org/10.1007/BF03216597.

Turkevich, J., Stevenson, P.C. \& Hillier, J. 1953. The Formation of Colloidal Gold. The Journal of Physical Chemistry, 57(7), pp.670-673. Available at: https://doi.org/10.1021/j150508a015.

Young, J.K., Lewinski, N.A., Langsner, R.J., Kennedy, L.C., Satyanarayan, A., Nammalvar, V., Lin, A.Y. \& Drezek, R.A. 2011. Size-controlled synthesis of monodispersed gold nanoparticles via carbon monoxide gas reduction. Nanoscale Research Letters, 6(art.numb.428). Available at: https://doi.org/10.1186/1556-276X-6-428.

Watzky, M.A. \& Finke, R.G. 1997. ransition Metal Nanocluster Formation Kinetic and Mechanistic Studies. A New Mechanism When Hydrogen Is the Reductant: Slow, Continuous Nucleation and Fast Autocatalytic Surface Growth. Journal of the American Chemical Society, 119(43), pp.10382-10400. Available at: https://doi.org/10.1021/ja9705102. 


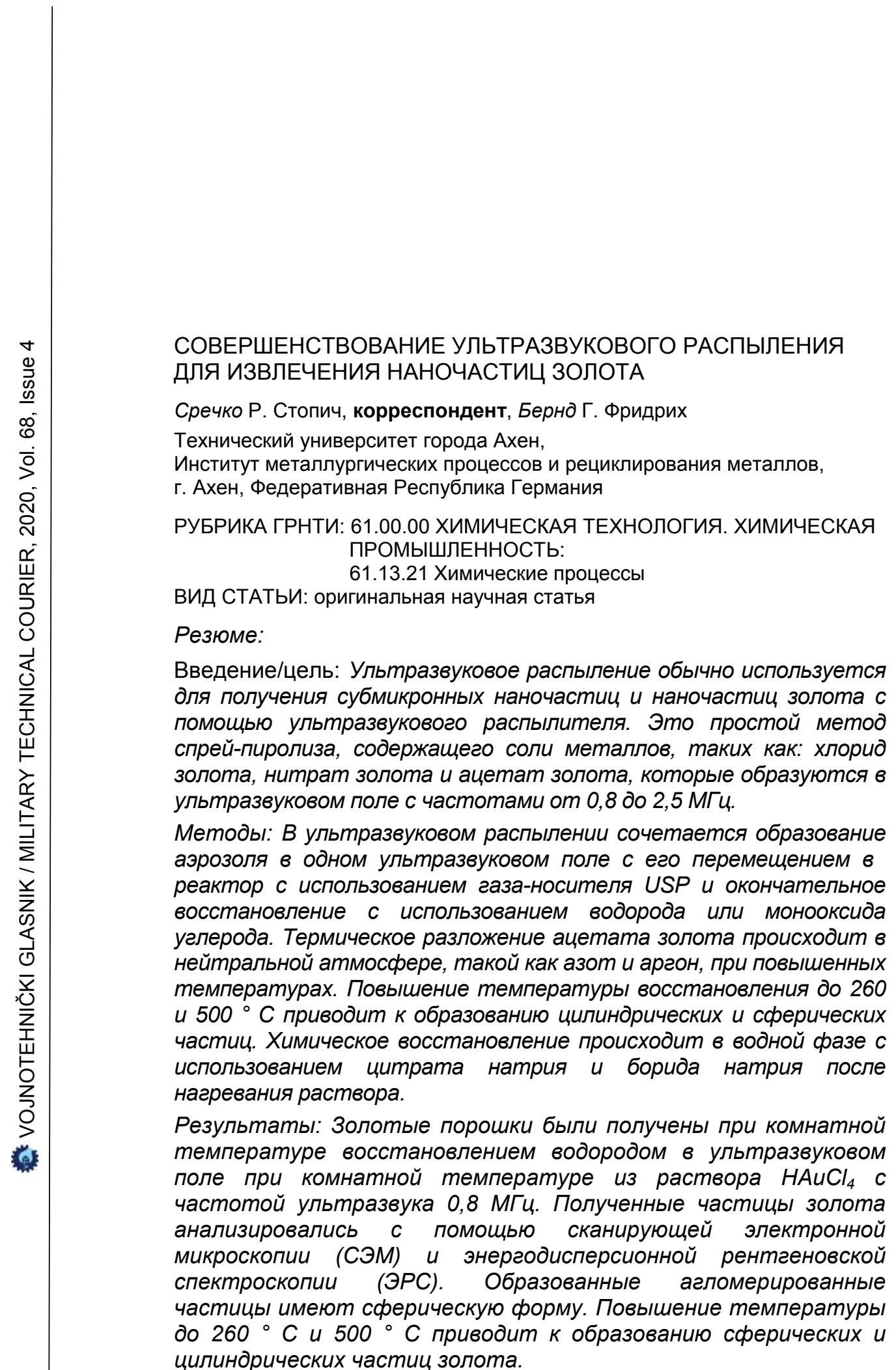

СОВЕРШЕНСТВОВАНИЕ УЛЬТРАЗВУКОВОГО РАСПЫЛЕНИЯ

Сречко Р. Стопич, корреспондент, Бернд Г. Фридрих

Технический университет города Ахен,

Институт металлургических процессов и рециклирования металлов,

Ахн, Федеративная Республика Германия ПРОМЫШЛЕННОСТЬ:

61.13.21 Химические процессы

ВИд СТАТЬИ: оригинальная научная статья помощью ультразвукового распылителя. Это простой метод спрей-пиролиза, содержащего соли металлов, таких как: хлорид олота, нитрат золота и ацетат золота, которые образуются в . реактор с использованием газа-носителя USP и окончательное восстановление с использованием водорода или монооксида углерода. Термическое разложение ацетата золота происходит нейтральной атмосфрере, такой как азот и аргон, при повышенных нагревания раствора.

Результаты: Золотые порошки были получены при комнатной температуре восстановлением водородом в ультразвуковом поле при комнатной температуре из раствора $\mathrm{HAuCl}_{4} \quad \mathrm{c}$ о, с помощью сканирующей электронной микроскопии (СЭМ) и энергодисперсионной рентгеновской спектроскопии (ЭРС). Образованные агломерированные до $260^{\circ} \mathrm{C}$ и $500^{\circ} \mathrm{C}$ приводит к образованию ссрерических и цилиндрических частиц золота.

Выводы: Новое усовершенствованное оборудование для извлечения золота путем ультразвукового распыления раствора $\mathrm{HAuCl}_{4}$ и восстановления водородом было предложено компанией PRIZMA, 2. Крагуевац, Республика Сербия, что позволяет контролировать процесс с лучшей защитой 
пьезопреобразователя в ультразвуковом поле и увеличивать образование аэрозоля и его перемещение в реакционную печь.

Ключевые слова: золото, совершенствование, ультразвуковое распыление, синтез.

\section{НАПРЕДАК У УЛТРАЗВУЧНОМ РАСПРШИВАЊУ ЗА СИНТЕЗУ} НАНОЧЕСТИЦА ЗЛАТА

Срећко Р. Стопић, аутор за преписку, Бернд Г. Фридрих

Технички универзитет у Ахену, Институт за процесну металургију и рециклирање метала, Ахен, Савезна Република Немачка

ОБЛАСТ: хемијске технологије

ВРСТА ЧЛАНКА: оригинални научни рад

\section{Сажетак:}

Увод/циљ: Ултразвучно распршивање обично је коришћено за припрему субмикронских и наночестица злата. То је једноставна метода синтезе из аеросола која садржи металне соли као што су злато-хлорид, злато-нитрат и злато-ацетат, који су формирани у ултразвучном пољу са фрреквенцијама измедју 0,8 и 2,5 MHz.

Mетоде: Ултразвучно распршивање комбинује фрормирање аеросола у једном ултразвучном пољу са његовим транспортом у реактор коришћењем носећег гаса USP и завршном редукцијом помоћу водоника или угљен-моноксида. До термичког разлагања злато-ацетата долази у неутралној атмоспфери као што је азот и аргон на повишеним температурама. Увећање температуре редукције до $260^{\circ} \mathrm{C}$ и $500^{\circ} \mathrm{C}$ води до добијања цилиндричних и сферних честица. Хемијска редукција дешава се у воденој фази коришћењем натријум-цитрата и натријум-борида након загревања раствора.

Резултати: Прахови злата добијени су на собној температури коришћењем редукције водоником у једном ултразвучном пољу на собној температури из раствора $\mathrm{HAuCl}_{4}$ при фрреквенци ултразвука од 0,8 MHz. Добијене честище злата анализиране су скенирајућом електронском микроскопијом (СЕМ) и енергетски дисперзивном спектроскопијом (ЕДС). Образоване честице су сферне и агломерисане. Увећање температуре до $260^{\circ} \mathrm{C}$ и $500^{\circ} \mathrm{C}$ води до формирања сфрерних и цилиндричних честица злата.

Закључак: Нову побољшану опрему за синтезу злата ултразвучним распршивањем раствора $\mathrm{HAuCl}_{4}$ и редукцијом водоником понудила је „Призма” из Крагујевца (Србија). Она омогућава контролисан процес са бољом затититом претварача 
у ултразвучном пољу и увећаном производњом аеросола и његовим транспортом у реакциону пећ.

Кључне речи: злато, напредак, ултразвучно распршивање, синтеза.

Paper received on / Дата получения работы / Датум пријема чланка: 12.08.2020. Manuscript corrections submitted on / Дата получения исправленной версии работы / Датум достављања исправки рукописа: 06.10.2020.

Paper accepted for publishing on / Дата окончательного согласования работы / Датум коначног прихватања чланка за објављивање: 08.10.2020.

( 2020 The Authors. Published by Vojnotehnički glasnik / Military Technical Courier (www.vtg.mod.gov.rs, втг.мо.упр.срб). This article is an open access article distributed under the terms and conditions of the Creative Commons Attribution license (http://creativecommons.org/licenses/by/3.0/rs/).

(c) 2020 Авторы. Опубликовано в «Военно-технический вестник / Vojnotehnički glasnik / Military Technical Courier» (www.vtg.mod.gov.rs, втг.мо.упр.срб). Данная статья в открытом доступе и распространяется в соответствии с лицензией «Creative Commons» (http://creativecommons.org/licenses/by/3.0/rs/).

( 2020 Аутори. Објавио Војнотехнички гласник / Vojnotehnički glasnik / Military Technical Courier (www.vtg.mod.gov.rs, втг.мо.упр.срб). Ово је чланак отвореног приступа и дистрибуира се у складу са Creative Commons licencom (http://creativecommons.org/licenses/by/3.0/rs/). 